\title{
SEMEN QUALITY, TESTOSTERONE LEVEL, SOME ENZYMES ACTIVITIES AND FERTILITY OF MALE APRI RABBITS TREATED WITH DIFFERENT LEVELS OF OLIVE LEAF EXTRACT
}

\author{
G.E. Younan; Hoda E. El-Gabry and W.A. Morsy \\ Animal Production Research Institute, Agricultural Research Center, Dokki, Egypt.
}

\section{SUMMARY}

$\mathrm{T}$

The present study was designed to investigate the efficacy of different dietary levels of ethanolic olive leaf extract (OLE), as a source of natural antioxidants, on quality and production of semen, some enzymes activities and testosterone concentration in blood serum and some seminal plasma characteristics of APRI rabbit bucks. A total of 24 mature rabbit bucks of APRI line (3-3.4 kg live body weight and 9-12 months of age) were divided into four similar groups, 6 bucks in each. Bucks in the $1^{\text {st }}$ group were fed a reference diet (17.75\% CP and $2500 \mathrm{DE} \mathrm{Kcal/Kg} \mathrm{diet)} \mathrm{without} \mathrm{any} \mathrm{supplements} \mathrm{(G1,} \mathrm{control).} \mathrm{While,} \mathrm{those} \mathrm{in} \mathrm{the}$ $2^{\text {nd }}(\mathrm{G} 2), 3^{\text {rd }}(\mathrm{G} 3)$ and $4^{\text {th }}(\mathrm{G} 4)$ treatment groups were fed the same diet supplemented with olive leaf extract at levels of $0.5,1$ and $1.5 \mathrm{ml} / \mathrm{kg}$ diet, respectively. Bucks were fed ad libitum on the experimental diets for a period of $17 \mathrm{wk}$ ( $8 \mathrm{wk}$ as a treatment period and $9 \mathrm{wk}$ as main semen collection period. Semen was evaluated physically, chemically and by transmission electron microscope (TEM). Results showed that all levels of dietary OLE supplementation increased $(\mathrm{P}<0.05)$ total semen volume in $\mathrm{G} 2$, G3 and G4 as compared to G1, being the highest in G4. Sperm characteristics, including percentages of progressive motility, livability, abnormality and cell concentration of spermatozoa improved $(\mathrm{P}<0.05)$ in $\mathrm{G} 3$ and $\mathrm{G} 4$ as compared to $\mathrm{G} 2$ and G1. Examination of sperm cells in all groups by TEM cleared enhancing the abnormalities in cell membrane and acrosome, axoneme as well as chromatin of spermatozoa in G4 as compared to other groups. Bucks in G4 showed the lowest $(\mathrm{P}<0.05)$ peroxidase and fructose testes in seminal plasma as compared to other groups. Activity of LDH in seminal plasma was higher $(\mathrm{P}<0.05)$ in all treatment groups than in control one, being the highest in G4 and the lowest in G1. Activity of AST and ALT and testosterone concentration in blood serum were not affected by OLE treatment. Activity of ALP in G4 and LDH activity in G3 and G4 increased $(\mathrm{P}<0.05)$ as compared to other groups. Kindling rate and reproductive index were improved $(\mathrm{P}<0.05)$ in rabbit does mated by bucks of $\mathrm{G} 3$ and $\mathrm{G} 4$ as compared to that of G2 and G1, being the highest in G4 $(81.67 \%$ ، 6.5). In conclusion, supplementation of the diet with olive leaf extract, in particular at a level of $1.5 \mathrm{ml} / \mathrm{kg}$, as a natural antioxidants source, is essential for improving reproductive performance and consequently semen quality and fertility of breeding rabbit bucks (natural or artificial mating) without adversely effects on healthy status.

Keywords: rabbit, antioxidant, oleuropein, sperm function, axoneme, kindling rate.

\section{INTRODUCTION}

Semen quality is the guarantee of successful insemination in breeding rabbits. Artificial Insemination (AI) is widely employed and this diffusion has contributed to the increase in knowledge of spermatozoa metabolism and management of rabbit bucks. There are many endogenous and exogenous factors affecting reproduction of rabbit bucks (Boiti et al., 2005) and thus it is crucial to define suitable protocols to improve sperm characteristics (Brun et al., 2002). Hence, it is possible to produce more doses of semen with higher "expected" fertility and with less variability.

Olive leaf (OL) is one of the potent source of plant polyphenols having antioxidant, antimicrobial, antiviral properties due to its rich phenolic contents. The most phenolic component of this content is oleuropein, which gives high palatability to olive or its olive oil. In order to utilize oleuropein and other bioactive components within OL effectively enough, they should be extracted from olive leaf. Olive leaf extract (OLE) contains compounds with potent antimicrobial activities against bacteria, fungi, and mycoplasma (Huang et al., 2003). Also, Aliabadi et al. (2012) indicated that using aqueous OLE had beneficial effects in controlling the microbial infections because it is a potent source of polyphenols having antioxidant, antimicrobial, anti-inflammatory and antiviral properties. Moreover, Sudjana et al. (2009)

The $16^{\text {th }}$ Scientific Conference for Animal Nutrition, Luxor - Aswan, $28^{\text {th }}$ Nov. $-1^{\text {th }}$ Dec., 2017 
showed the antimicrobial activity of commercial olive leaf extracts (Olea europaea) against campylobacter jejuni (CJ), Helicobacter pylori (HP) and methicillin-resistant Staphylococcus aureus. These extracts play a role in regulating the composition of the gastric flora by selectively reducing levels of HP and CJ. The reports describing antimicrobial properties of phenolic compounds in olive products refer to compounds obtained from olive fruit, particularly hydroxyl tyrosol and oleuropein (Periera et al., 2007).

In addition, Juven et al. (1972) observed that oleuropein affected a significant leakage of glutamate, potassium and inorganic phosphate from Lactobacillus plantarum. Oleuropein had no effect on the rate of glycolysis when added to resting cells of $L$. plantarum but it caused a decrease in the ATP content of the cells. Shafey et al. (2013) found that dietary addition of $50 \mathrm{~g}$ olive leaf $/ \mathrm{kg}$ altered small intestine measurements and reduced live and carcass weights of broiler chickens. Cayan and Erener (2015) observed that olive leaf powder $(1,2$, or $3 \%)$ can be used for reducing egg yolk cholesterol content and egg yolk coloring agent in layer diets.

In rabbits, Dub and Dugani (2013) studied the effect of ethanolic olive leaf extract (EOLE) at levels of 100 and $200 \mathrm{mg} / \mathrm{kg}$ per day. They found that EOLE can modify the extrinsic coagulation pathway as evidenced by the prolongation of prothrombin time and changes in thrombus morphology, enough to justify further research to evaluate its possible antithrombotic effects.

The available data on the protective properties of OLE on the function of the testes and accessory sex glands, in terms of semen quality and testosterone production in rabbits are rare. Therefore, the present study was designed to investigate the efficacy of different dietary levels of ethanolic olive leaf extract, as a source of antioxidants, on quality and production of semen, some enzyme activity and testosterone concentration in blood serum, and some characteristics of seminal plasma of APRI rabbit bucks.

\section{MATERIALS AND METHODS}

The present study was carried out at rabbit farm of Sakha station, belonging to Animal Production Research Institute (APRI), Agricultural Research Center, Ministry of Agriculture, Egypt during the period from March to June 2017.

Animals and Management:

A total of 24 mature rabbit bucks of APRI line (3-3.4 kg live body weight and 9-12 months of age) were divided into four similar groups, 6 bucks in each. Bucks in the $1^{\text {st }}$ group were fed complete fed diet $(17.75 \%$ $\mathrm{CP}$ and $2500 \mathrm{DE} \mathrm{Kcal} / \mathrm{Kg}$ diet)) without any supplements (G1, control). While, those in the $2^{\text {nd }}(\mathrm{G} 2), 3^{\text {rd }}(\mathrm{G} 3)$ and $4^{\text {th }}(\mathrm{G} 4)$ treatment groups were fed the same diet supplemented with olive leaf extract at levels of $0.5,1$ and $1.5 \mathrm{ml} / \mathrm{kg}$ diet, respectively. Ingredients and chemical composition of the complete feed diet fed to rabbit bucks in all groups are shown in Table (1).

Table (1): Feed ingredients and calculated chemical analysis of the reference diet.

\begin{tabular}{lclcc}
\hline Ingredient & $\%$ & \multicolumn{2}{l}{ Calculated chemical analysis } \\
\hline Berseem hay (Trifolium alexandrinum) & 30.05 & Crude protein & $\%$ & 17.75 \\
Barley & 24.60 & Digestible energy & Kcal/Kg diet & 2500 \\
Wheat bran & 21.50 & Crude fiber & $\%$ & 12.38 \\
Soybean meal $(44 \% \mathrm{CP})$ & 17.50 & Ether extract & $\%$ & 2.27 \\
Molasses & 3.00 & Calcium & $\%$ & 1.24 \\
Di-calcium phosphate & 1.60 & Total phosphorus & $\%$ & 0.80 \\
Limestone & 0.95 & Lysine & $\%$ & 0.98 \\
Sodium chloride $(\mathrm{NaCl})$ & 0.30 & Methionine & $\%$ & 0.46 \\
Vitamin \& Mineral Mixture* & 0.30 & Methionine + Cystine & $\%$ & 0.76 \\
DL-Methionine & 0.20 & Sodium & $\%$ & 0.16 \\
\hline
\end{tabular}

*Supplied per kilogram of diet: Vitamin A, $6000 \mathrm{IU}$; Vitamin $D_{3}$, $900 \mathrm{IU}$; Vitamin E, $40 \mathrm{mg}$; Vitamin $\mathrm{K}_{3}, 2 \mathrm{mg}$; Vitamin $B_{1}, 2 \mathrm{mg}$; Vitamin $B_{2}, 4 \mathrm{mg}$; Vitamin $B_{6}, 2 \mathrm{mg}$; Pantothenic acid, $10 \mathrm{mg}$; Vitamin $B_{12}, 0.01 \mathrm{mg}$; Niacin, $50 \mathrm{mg}$; Folic acid, $3 \mathrm{mg}$; Biotin, $0.05 \mathrm{mg}$; Choline, $250 \mathrm{mg} ; \mathrm{Fe}, 50 \mathrm{mg} ; \mathrm{Mn}, 85 \mathrm{mg} ; \mathrm{Cu}, 5 \mathrm{mg} ; \mathrm{Co}, 0.1 \mathrm{mg} ; \mathrm{Se}, 0,1 \mathrm{mg} ; \mathrm{I}, 0.2 \mathrm{mg}$ and $\mathrm{Zn}, 50 \mathrm{mg}$. 
Bucks were individually housed in wire cages supplied with nipple drinkers and fed ad libitum on the diets for an experimental period of 17 weeks, 8 weeks as a treatment period and 9 weeks as main semen collection period.

\section{Preparation of olive leaf extract (OLE):}

Olive leaves used in this study were collected in winter (February) from Borg El-Arab region, Alexandria governorate, Egypt. The collected olive leaves were cleaned from extraneous matter, shade-dried at room temperature with passive ventilation and crushed into a fine powder. The air dried plant materials were ground in a blender with a particular size to ensure the plant powders in identical size. The powder $(50 \mathrm{~g})$ was macerated in $150 \mathrm{ml}$ ethanol (75\%) and allowed to extract for $48 \mathrm{~h}$. The resultant (dark green-brown mixture) was filtered. The crude extracts were kept in refrigerator in glass bottles until the further experiments.

\section{Semen collection:}

Semen was collected twice weekly form bucks in all groups using artificial vagina of rabbits. Semen was collected before feeding at 8.00 a.m. Gel plug was removed immediately after ejaculation and semen was kept at $35-37{ }^{\circ} \mathrm{C}$ in water bath, then the collected semen was taken immediately to the laboratory.

\section{Semen evaluation:}

Immediately after collection, semen $\mathrm{pH}$ value was determined by $\mathrm{pH}$ meter pen. Semen volume without gel fraction) and gel volume were measured by graduated collection test tube. Percentages of progressive motility, livability and abnormality of spermatozoa were determined in semen diluted with saline solution at a rate of $1: 10$. Sperm progressive motility was assessed using research microscope with warmed stage $\left(37^{\circ} \mathrm{C}\right)$ according to Amman and Hammerstedt (1980). Sperm livability was determined using eosin-nigrosin mixture stain according to Hackett and Macpherson (1965). Live spermatozoa (unstained ones) and dead spermatozoa (stained ones) were counted in field of a total of 200 spermatozoa, then percentage of live spermatozoa was calculated. Sperm abnormality percentage was determined during the examination of live/dead sperm percentage at a high power magnification (400x), according to the classification adopted by Blom (1983). Sperm cell concentration (SCC) was evaluated by Neubauer hemocytometer.

The response of spermatozoa to Hypo-Osmotic Swelling-test (HOS-t) was conducted at osmolarity level of $50 \mathrm{mOsm} / \mathrm{l}$ for $30 \mathrm{~min}$, in term of determining curled sperm percentage.

\section{Transmission electron microscope (TEM) evaluation of semen samples}

Semen samples were processed for TEM as described in (Oliveira et al., 2011) with some modifications. Briefly, samples $(500 \mu \mathrm{L})$ were centrifuged and resuspended in a fixative solution composed of $4 \%$ glutaraldehyde in Dulbecco's modified phosphate buffered saline for $2 \mathrm{~h}$ at $4^{\circ} \mathrm{C}$. Samples were then washed and post-fixed in $1 \%$ osmium tetroxide for $1 \mathrm{~h}$ at room temperature. Fixed samples were then dehydrated in an ethanol gradient, treated with propylene oxide and embedded in Epon resin (Epon 812; Fluka Chemie, Switzerland) and ultrathin-sectioned $(60-70 \mathrm{~nm})$ for TEM. Ultrathin sections were observed at $80 \mathrm{kV}$ using a JEOL 2100 TEM at $80 \mathrm{KV}$ at Faculty of Agriculture, Mansoura University, Egypt. The sperm ultrastructure was examined in 100 sperm cells per sample.

\section{Sperm production:}

Sperm production (outputs), in terms of total (TSO), motile (MSO), live (LSO), normal (NSO) and functional (FSO) sperm outputs per ejaculate were calculated as the following:

$$
\begin{aligned}
& \text { TSO/ejaculate }=\text { ejaculate volume }(\mathrm{ml}) \times \text { SCC }(\text { sperm } / \mathrm{ml}) \\
& \text { MSO/ejaculate }=\text { TSO/ejaculate } x \text { sperm motility }(\%) \\
& \text { LSO/ejaculate }=\text { TSO/ejaculate } x \text { live sperm }(\%) \\
& N S O=\{\text { TSO/ejaculate } x(\text { sperm abnormality- } 100\} / 100 \\
& F S O=[\text { TSO/ejaculate } x \text { sperm motility }(\%) \times \text { sperm livability }(\%) \times \text { sperm normality }(\%)]
\end{aligned}
$$




\section{Seminal plasma sampling:}

At the last collection week, semen samples were taken from each buck in all experimental groups into tubes and incubated for one hour in water bath at $37^{\circ} \mathrm{C}$, centrifuged at $1500 \mathrm{rpm}$ for 15 minutes, and then seminal plasma was separated and frozen at $-20{ }^{\circ} \mathrm{C}$ until assaying peroxidase and fructose tests by determination of peroxidase-positive white blood cells and fructose concentration in seminal plasma according to Aitken (1989) and Foreman et al. (1973), respectively.

\section{Blood sampling:}

Blood samples were taken from the ear vein of each buck in all experimental groups into tubes. The samples were centrifuged at $3000 \mathrm{rpm}$ for 15 minutes and blood plasma was separated and frozen at $-20{ }^{\circ} \mathrm{C}$ until assaying the testosterone concentration using a double antibody radioimmunoassay (Diagnostic Products Corporation Kits) according to McCann and Kirkish (1985). However, activity of AST, ALT, ALP and LDH was determined using commercial kits (Diagnostic Products Corporation Kits) according to Young, 1990, Sherwin et al.1984, and Belfield and Goldberg (1971).

\section{Statistical analysis:}

Data were analyzed by two-way (treatment $\mathrm{x}$ collection week) analysis of variance (ANOVA) using the General Linear Model (GLM) procedure, and also personal correlation coefficients were calculated using computer program of SAS (2004). Significant differences among means were set at $\mathrm{P}<0.05$ using Duncan's multiple range test (Duncan, 1955).

The percentage values were subjected to arcsine transformation before performing the analysis of variance. Means were presented after being recalculated from the transformed values to percentages. Data were expressed as mean \pm standard error.

\section{RESULTS AND DISCUSSION}

\section{Semen characteristics:}

\section{Semen volume:}

Data in Table (2) show that all levels of dietary OLE supplementation significantly $(\mathrm{P}<0.05)$ increased total semen volume in G2, G3 and G4 as compared to control (G1), being the highest in G4 (1.5 ml/kg diet). This increase was associated with significant $(\mathrm{P}<0.05)$ increase in net semen volume and insignificant increase in gel volume and semen $\mathrm{pH}$ value. It is of interest to note that the effect of collection week or its interaction with OLE treatment was insignificant on volumes and $\mathrm{pH}$ value of semen. Such results indicated beneficial effects of dietary addition of OLE at a level of $1.5 \mathrm{ml} / \mathrm{kg}$ diet) on semen volume of rabbit bucks.

Table (2). Semen physical characteristics of APRI rabbit bucks fed different olive leaf extract levels at collection weeks.

\begin{tabular}{|c|c|c|c|c|}
\hline Variable & $\begin{array}{c}\text { Total semen volume } \\
(\mathrm{ml})\end{array}$ & $\begin{array}{l}\text { Semen gel volume } \\
(\mathrm{ml})\end{array}$ & $\begin{array}{l}\text { Net semen volume } \\
(\mathrm{ml})\end{array}$ & Semen $\mathrm{pH}$ value \\
\hline \multicolumn{5}{|c|}{ Effect of olive leaf extract level : } \\
\hline G1 (control) & $0.756^{\mathrm{c}} \pm 0.038$ & $0.133 \pm 0.055$ & $0.622^{\mathrm{b}} \pm 0.055$ & $7.208 \pm 0.074$ \\
\hline $\mathrm{G} 2(0.5 \mathrm{ml} / \mathrm{kg}$ diet $)$ & $1.056^{\mathrm{b}} \pm 0.082$ & $0.200 \pm 0.069$ & $0.856^{\mathrm{a}} \pm 0.067$ & $7.362 \pm 0.071$ \\
\hline $\mathrm{G} 3(1.0 \mathrm{ml} / \mathrm{kg}$ diet $)$ & $1.356^{\mathrm{a}} \pm 0.097$ & $0.356 \pm 0.078$ & $1.000^{\mathrm{a}} \pm 0.044$ & $7.371 \pm 0.096$ \\
\hline G4 (1.5 ml/kg diet) & $1.400^{\mathrm{a}} \pm 0.126$ & $0.333 \pm 0.088$ & $1.067^{\mathrm{a}} \pm 0.088$ & $7.491 \pm 0.071$ \\
\hline \multicolumn{5}{|c|}{ Effect of collection week: } \\
\hline $1-3$ & $1.092 \pm 0.097$ & $0.250 \pm 0.056$ & $0.842 \pm 0.077$ & $7.258 \pm 0.073$ \\
\hline $4-6$ & $1.117 \pm 0.121$ & $0.242 \pm 0.066$ & $0.875 \pm 0.076$ & $7.408 \pm 0.079$ \\
\hline $7-9$ & $1.217 \pm 0.109$ & $0.275 \pm 0.082$ & $0.942 \pm 0.071$ & $7.408 \pm 0.056$ \\
\hline \multicolumn{5}{|c|}{ Interaction between olive leaf extract levels and collection week: } \\
\hline P-value & 0.9603 & 0.9310 & 0.9999 & 0.4409 \\
\hline
\end{tabular}


The present results revealed that elevation of total semen volume was due to increasing net volume rather than gel volume, which may indicate pronounced effect of OLE treatment, directly on function of accessory sex (seminal vesicles, prostate and Cowper's glands) or indirectly on testosterone secretion, which has vital role on accessory sex gland function in rabbit bucks (Abdel-Khalek et al., 2005). In this way, Awoniyi (2010) stated that, improving semen volume with increasing testosterone concentration may reveal pronounced effect on accessory sex glands and testicular tissues (spermatocytes) within the somniferous tubules of the testis as well as on epididymal spermatozoa. Generally, the present values of net semen volume in all treatment and control groups are within the normal range of rabbits as reported by Abdel-Khalek et al. (2005) on NZW bucks and Mangiagalli et al. (2012) on hybrid Martini male rabbits, but it was higher than that reported by Sheteifa and Morsy (2014) on APRI bucks. The present study revealed positive relationship between $\mathrm{pH}$ values and ejaculate volume. The obtained semen $\mathrm{pH}$ values were similar to that obtained on APRI buck semen (Sheteifa and Morsy, 2014), higher than that reported on NZW rabbits (Abdel-Khalek et al., 2005) and lower than that reported on Californian rabbit semen (Ongun et al., 2010).

\section{Physical characteristics of spermatozoa:}

Results in Table (3) show that sperm characteristics studied including progressive motility (PM) and sperm livability (SL) of spermatozoa significantly ( $\mathrm{P}<0.05)$ improved in G3 and G4 as compared to G2 and G1. However, sperm abnormality (SA) and sperm cell concentration (SCC) of spermatozoa significantly $(\mathrm{P}<0.05)$ improved in all treatment groups $(\mathrm{G} 2, \mathrm{G} 3$ and $\mathrm{G} 4)$ as compared to G1. Generally, bucks in G4 showed significantly $(\mathrm{P}<0.05)$ the best semen quality as compared to other groups. As affected by collection week, sperm motility significantly $(\mathrm{P}<0.05)$ improved after three collection weeks. While, both sperm livability and abnormality significantly $(\mathrm{P}<0.05)$ improved after six collection weeks. Yet, sperm cell concentration showed gradual improvement by advancing collection week, but this change was not significant (Table 3).

Table (3). Sperm characteristics in semen of APRI rabbit bucks fed different olive leaf extract levels at collection weeks.

\begin{tabular}{|c|c|c|c|c|}
\hline Variable & $\begin{array}{c}\text { Progressive } \\
\text { sperm motility } \\
(\%)\end{array}$ & $\begin{array}{c}\text { Sperm livability } \\
(\%)\end{array}$ & $\begin{array}{c}\text { Sperm } \\
\text { abnormality }(\%)\end{array}$ & $\begin{array}{c}\text { Sperm cell } \\
\text { concentration } \\
\left(\times 10^{6} / \mathrm{ml}\right) \\
\end{array}$ \\
\hline \multicolumn{5}{|c|}{ Effect of olive leaf extract level: } \\
\hline G1 (control) & $71.44^{\mathrm{b}} \pm 3.25$ & $80.56^{\mathrm{b}} \pm 1.20$ & $12.22^{\mathrm{a}} \pm 0.57$ & $115.11^{\mathrm{c}} \pm 6.26$ \\
\hline $\mathrm{G} 2(0.5 \mathrm{ml} / \mathrm{kg}$ diet $)$ & $79.67^{\mathrm{ab}} \pm 2.65$ & $82.89^{b} \pm 1.66$ & $10.11^{\mathrm{b}} \pm 0.98$ & $216.33^{b} \pm 12.75$ \\
\hline $\mathrm{G} 3(1.0 \mathrm{ml} / \mathrm{kg}$ diet $)$ & $82.45^{\mathrm{a}} \pm 2.26$ & $85.89^{\mathrm{a}} \pm 1.26$ & $9.22^{\mathrm{b}} \pm 0.78$ & $238.67^{\mathrm{ab}} \pm 10.14$ \\
\hline G4 (1.5 ml/kg diet $)$ & $82.56^{\mathrm{a}} \pm 1.12$ & $86.78^{\mathrm{a}} \pm 1.19$ & $8.56^{\mathrm{b}} \pm 0.82$ & $253.56^{\mathrm{a}} \pm 11.49$ \\
\hline \multicolumn{5}{|c|}{ Effect of collection week: } \\
\hline $1-3$ & $75.08^{\mathrm{b}} \pm 2.96$ & $81.25^{\mathrm{b}} \pm 1.40$ & $11.50^{\mathrm{a}} \pm 0.76$ & $194.5 \pm 17.12$ \\
\hline $4-6$ & $80.58^{\mathrm{a}} \pm 1.96$ & $83.00^{\mathrm{b}} \pm 0.78$ & $10.42^{\mathrm{a}} \pm 0.54$ & $204.4 \pm 16.85$ \\
\hline $7-9$ & $81.41^{\mathrm{a}} \pm 1.15$ & $87.83^{\mathrm{a}} \pm 1.09$ & $8.17^{\mathrm{b}} \pm 0.72$ & $218.8 \pm 20.78$ \\
\hline \multicolumn{5}{|c|}{ Interaction between olive leaf extract levels and collection week: } \\
\hline P-value & 0.0001 & 0.8972 & 0.6381 & 0.7930 \\
\hline
\end{tabular}

Analysis of variance revealed that the effect of interaction between treatment and collection week was highly significant $(\mathrm{P}<0.0001)$ only for sperm motility, reflecting increasing sperm motility in all groups after three collection weeks, being the highest in G2 than in other groups, then G1 showed marked increase versus stability in motility of other groups after 6 collection weeks, but percentage of sperm motility was higher in treatment groups than in control at all collection weeks (Fig. 1). 


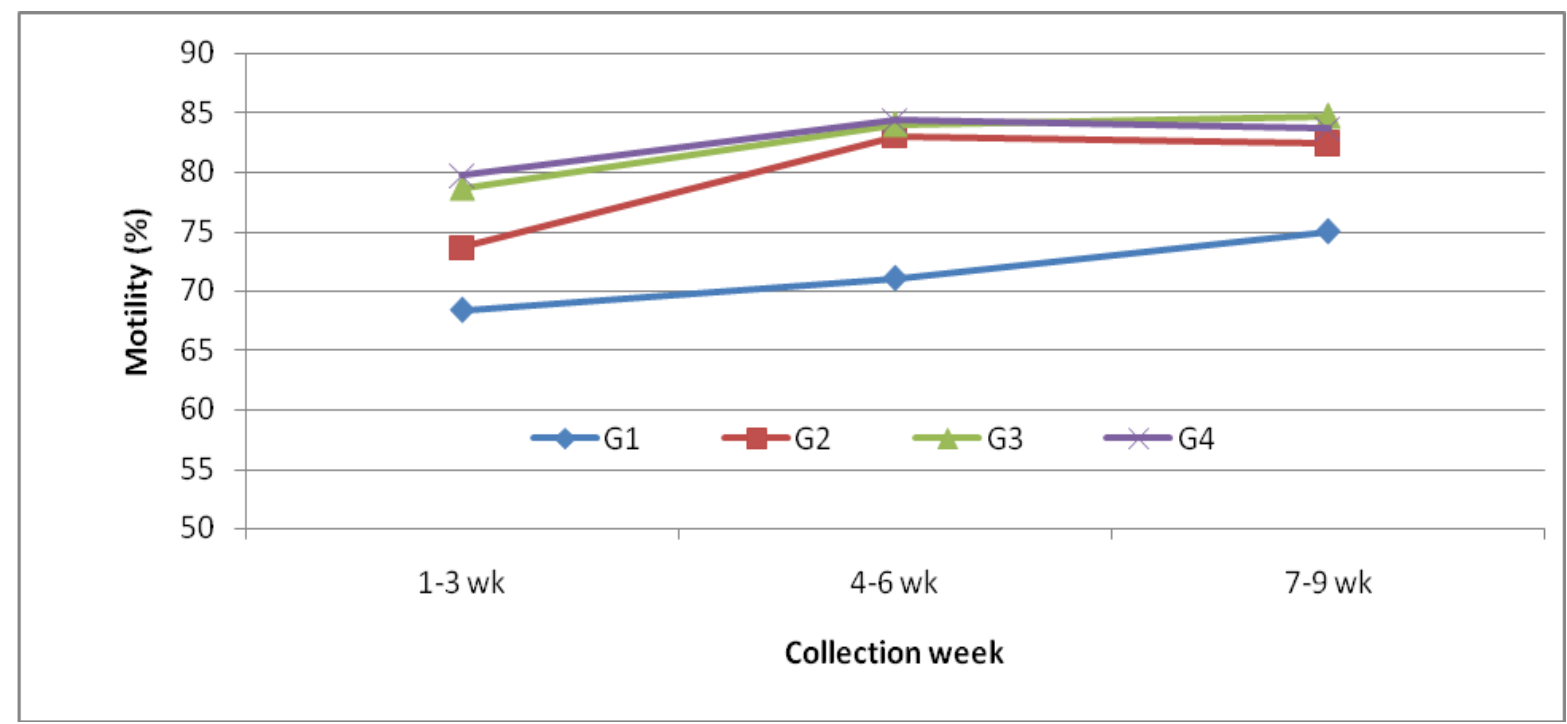

Fig. (1): Change in sperm progressive motility percentage in semen of rabbit bucks in experimental groups at different collection weeks.

\section{Sperm cell membrane integrity (Hypo-osmotic swelling-test, HOS-t):}

Results presented in Table (4) revealed that spermatozoa in semen of bucks in all treatment groups at the last collection week showed significantly $(\mathrm{P}<0.05)$ higher response to HOS-t in term of increasing parentage of curled spermatozoa than that of the control bucks, being the highest in G4. It is of interest to mention that parentage of curled spermatozoa significantly and positively correlated with each of sperm output parameters, being the strongest with normal and live sperm outputs $(r=0.828$ and $0.826, \mathrm{P}<0.001)$, followed by functional, total, and motile sperm outputs $(\mathrm{r}=0.820,0.818$ and $0.810, \mathrm{P}<0.01)$. These results indicated impact of all OLE levels on production of spermatozoa with intact membranes.

Table ( 4). Hypo-osmotic Swelling-test (HOS-t) in semen of APRI rabbit bucks fed different olive leaf extract levels at collection weeks and its correlation coefficients with sperm outputs.

\begin{tabular}{lc}
\hline Item & HOS-t (curled spermatozoa \%) \\
\hline Effect of olive leaf extract level : & $29.67^{\mathrm{c}} \pm 1.20$ \\
$\mathrm{G} 1$ (control) & $38.67^{\mathrm{b}} \pm 2.40$ \\
$\mathrm{G} 2(0.5 \mathrm{ml} / \mathrm{kg}$ diet) & $43.67^{\mathrm{ab}} \pm 2.19$ \\
$\mathrm{G} 3(1.0 \mathrm{ml} / \mathrm{kg}$ diet) & $46.33^{\mathrm{a}} \pm 1.76$ \\
$\mathrm{G} 4(1.5 \mathrm{ml} / \mathrm{kg}$ diet$)$ & $0.818^{* *}$ \\
Correlation coefficients of Hypo-osmotic Swelling-test with: \\
Total sperm output & $0.810^{* *}$ \\
Motile sperm output & $0.826^{* * *}$ \\
Live sperm output & $0.828^{* * *}$ \\
Normal sperm output & $0.820^{* *}$ \\
Functional sperm output & \\
\hline a, $b$ and $:$ Means in the same column with different superscripts are significantly different $(P<0.05)$. \\
** Significant at $P<0.01 . \quad * * *$ Significant at $P<0.001$.
\end{tabular}

\section{Ultrastructural examination:}

The morphological examination of spermatozoa using electron microscopy indicated the normal membrane integrity and intact acrosome of spermatozoa in semen of all groups, being the best semen of bucks in G4, followed by G3, G2 and G1, respectively. Longitudinal ultrathin sections in sperm cells of semen in all groups showed 
intact sperm with normal head, neck and mid piece (A) (Fig. 2a), sperm head showing normal nucleus (N) with homogenous condensed chromatin surrounded by normal acrosomal membrane (AM) and normal axoneme (Fig. 2b), and intact main piece of tail with normal microtubules (MT) and plasma membrane (PM) (Fig. 2c).

On the other hand, some abnormalities at different levels were observed head of some sperm cells in semen of G3. Longitudinal ultrathin sections in sperm cells of buck semen in G3 showed sperm with head abnormalities, in terms of slightly swollen acrosomal membrane (SAM) and damaged chromatin (DC) (Fig. 3a), swollen head spermatozoa (SH) (Fig. 3b), and damaged chromatin and abnormal acrosomal membrane (Fig. 3c). Other defected spermatozoa were observed in semen of bucks in G2, in terms of normal plasma membrane with unclear arrangement in axoneme (AX) of different segments of the main piece (Fig. 4a), and slight damaged acrosomal membrane (AM) (Fig. 4b), and intact mid piece with normal spiral mitochondria (MI), normal axoneme (AX), and lateral and central microtubules (MT) (Fig. 4c).

It is of interest to not that examination of ultrathin sections in sperm cells of buck semen in G1 (control group) revealed also normal plasma membrane with pronounced swelling in acrosomal membrane (SAM) in some sperm heads versus intact acrosomal membrane (IAM) (Fig. 5a and b), and slight swelling and breakdown in the acrosomal membrane (AM) (Fig. 5c). Similar abnormalities were observed in frozen Friesian semen using electron microscopy Hassan (2015).

As found in improving semen volume of rabbit bucks as affected by OLE (Table 2), the obtained results (Tables 3 and 4) indicated that OLE had beneficial effects also on function and membrane integrity of spermatozoa in semen of bucks in term of increasing progressive motility, livability and membrane integrity of spermatozoa at levels of 1.0 or $1.5 \mathrm{ml} / \mathrm{kg}$ diet, while all OLE levels had impact on reducing sperm abnormality and increasing sperm cell concentration in rabbit semen. The recorded improvement in semen quality was observed after three collection weeks. The highest volume and the best quality of semen were obtained from bucks treated with $1.5 \mathrm{ml} / \mathrm{kg}$ diet.

In accordance with the present results, natural antioxidants as Moringa oleifera (MO) leaf extract (Khalifa et al., 2016) or MO leaf meal (Oyeyemi et al., 2008) significantly increased the sperm physical characteristics (motility, viability and membrane integrity) of rabbit bucks. The later authors observed a positive correlation between inclusion MO leaf meal and sperm concentration in rabbits. In this respect, Dacheux et al. (2003) found that epididymis is known to play a major role in the final development of motility, fertilizing ability and sperm storage. Sperm concentration can increase during epididymal transit with a simultaneous increase in sperm metabolism and the possibility of ROS threatens the survival of these male gametes. These findings may proved the beneficial effects of in vivo OLE treatment as antioxidant on improving most sperm characteristics, including motility, abnormality and concentration and may be attributed to the prevention of excessive generation of free radicals produced by sperm by means of the antioxidant properties of olive leaf extract. Also, Purdy et al. (2004) demonstrated that flavonoids caused an increase sperm motility. Moreovere, Eid et al. (2006) found that a higher antioxidant intake was associated with greater sperm numbers and motility. However, Abu et al. (2013) results showed that MO leaf meal did not significantly influence sperm motility and concentration of the rabbits. These results supported the obtained results concerning improvement in sperm motility in association with marked increase in sperm cell concentration and reducing sperm abnormality without pronounced effect on sperm livability as affected by in vivo OLE treatment.

Oxidative stress plays a prominent role in patho-physiology of reproductive malfunction and infertility in animals and humans (Feldman et al., 2000). A shift in pro-oxidant and oxidant status could lead to reactive oxygen species (ROS), but a change in antioxidant activities is frequently used as an important indicator of ROS and the antioxidant defense status determines the extent to which oxidative damage occurs in the sperm (Sikka, 2001; Ong et al., 2002). The generation of ROS by sperm is a normal physiological process, however a shift between ROS production and scavenging activity is deleterious to sperm and it has been shown to be associated with male infertility (Sharma and Agarwal, 1996). 


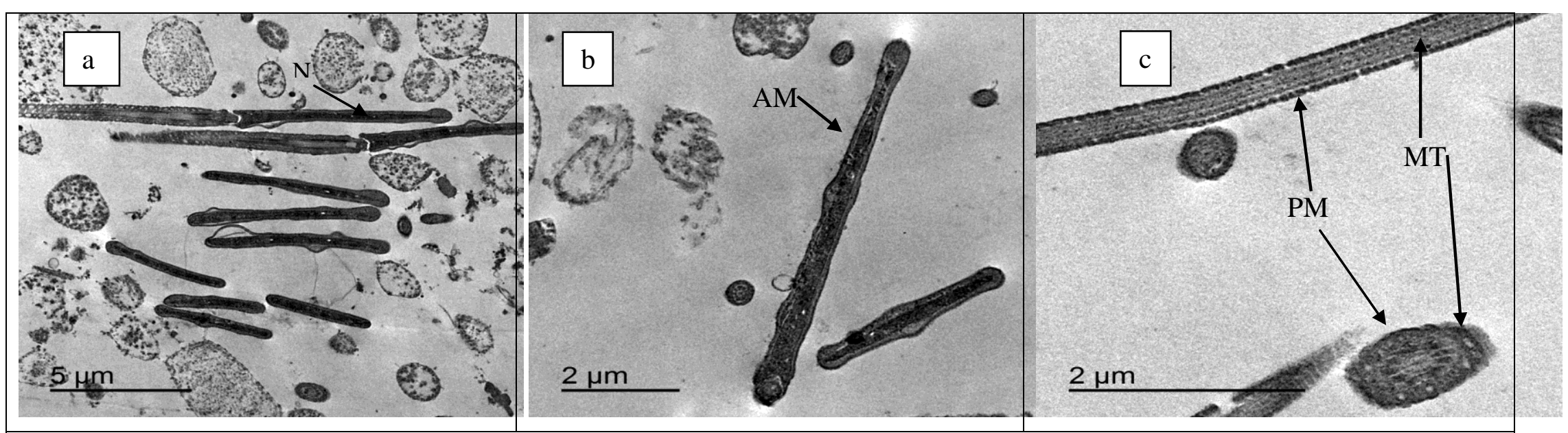

2): Longitudinal ultrathin section in sperm cells in semen of bucks in G4 showing a: intact sperm with normal head, neck and mid piece (a), (b): sperm head showing normal nucleus $(N)$ with homogenous condensed chromatin surrounded by normal acrosomal membrane (AM) and normal axoneme, and c: intact main piece of tail with normal microtubules (MT) and plasma membrane (PM).
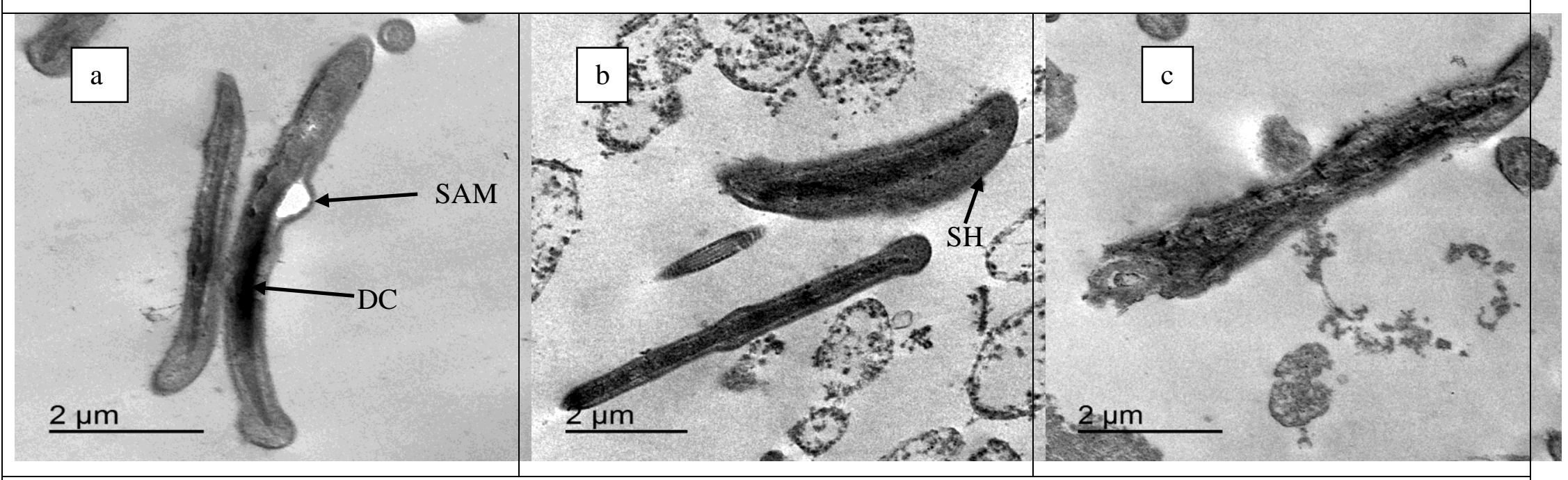

Longitudinal ultrathin section in sperm cells of buck semen in G3 showing sperm with head abnormalities, being a: slight swelling in acrosomal membrane (SAM), damaged chromatin (DC), b: sperm cell with swollen head (SH), and c: sperm head with damaged chromatin and acrosomal membrane.

The $16^{\text {th }}$ Scientific Conference for Animal Nutrition, Luxor - Aswan, $28^{\text {th }}$ Nov. $-1^{\text {th }}$ Dec., 2017 


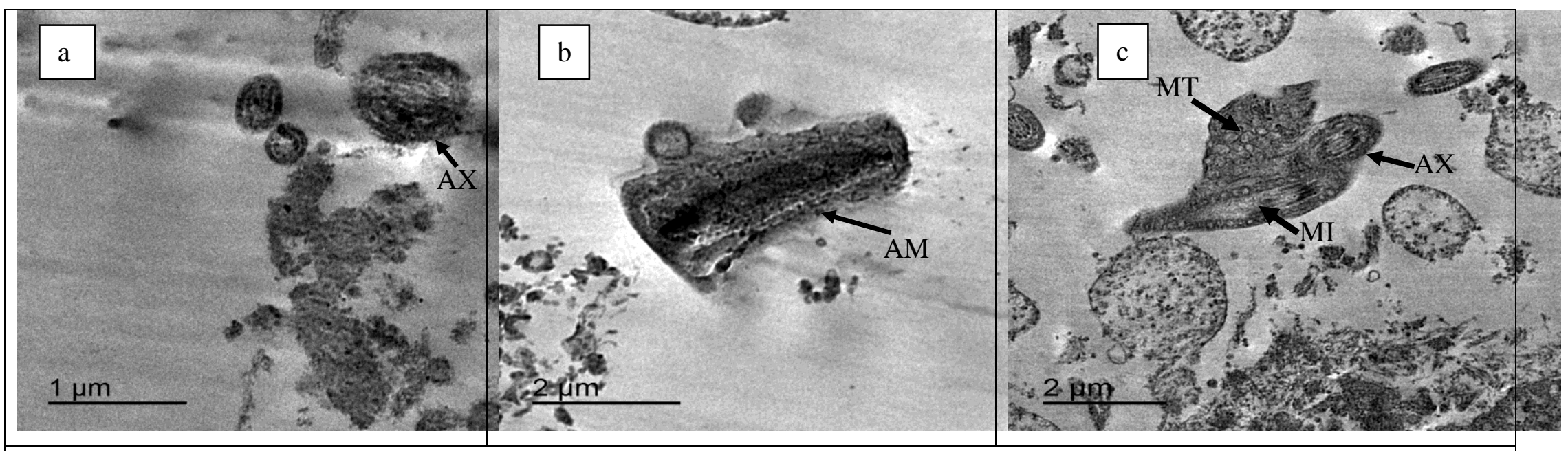

Ultrathin section of sperm in semen of bucks in G2 showing a: normal plasma membrane with unclear arrangement in axoneme (AX) of different segments of the main piece, as well as b: slight damaged acrosomal membrane (AM), and c: intact mid piece with normal spiral mitochondria (MI), normal axoneme (AX), and lateral and central microtubules (MT).

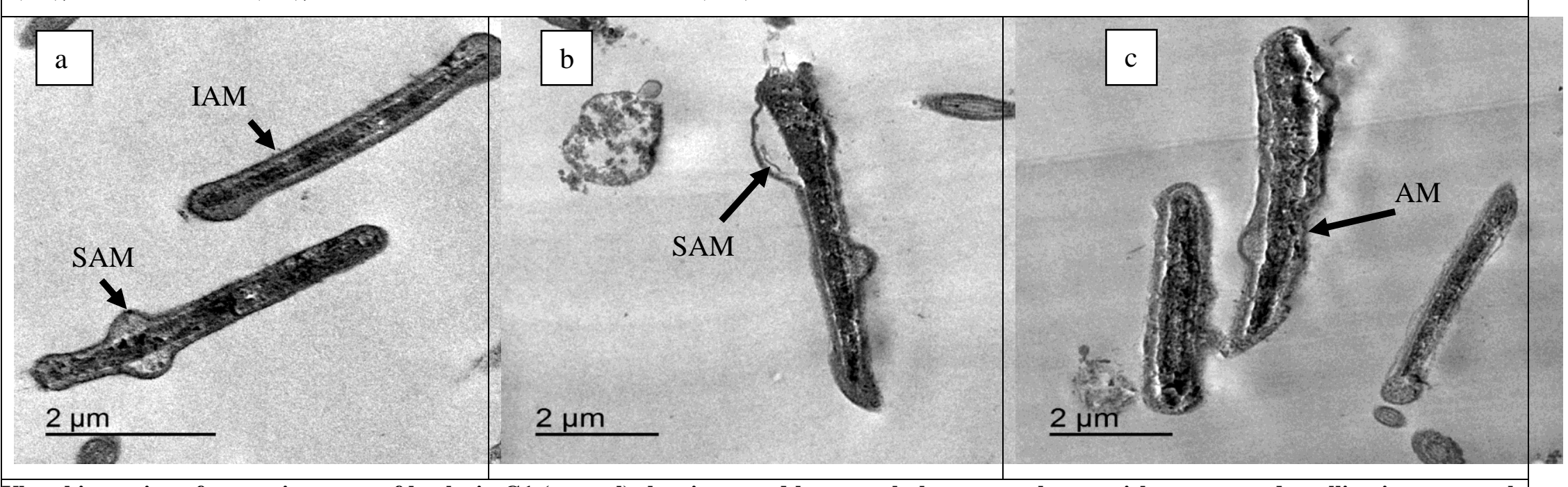

Ultrathin section of sperm in semen of bucks in G1 (control) showing a and b: normal plasma membrane with pronounced swelling in acrosomal membrane (SAM) in some sperm heads versus intact acrosomal membrane (IAM), and c: slight swelling and breakdown in the acrosomal membrane (AM). 
Based on the present results in tem of improving semen quality of bucks treated with OLE, several authors indicated that olive leaf or its extract is one of the potent source of plant polyphenols having antioxidant, antimicrobial (against bacteria, fungi, and mycoplasma), antiviral and anti-inflammatory, properties (Suresh et al., 2009; Aliabadi et al,. 2012). The most phenolic components of this content is oleuropein, which gives the better taste to olive and its oil (Huang et al., 2003; Periera et al., 2007). Flavonoids and phenolic compounds obtained from olive leaf are known to have diverse biological activities and may also be responsible for the pharmacological actions of olive leaf or, at least synergistically reinforcing those actions (Abaza et al., 2011). Even though, there are several groups, remarkable for determination of antioxidant capacity of flavonoids, it is mainly the o-dihydroxy (cathechol) structure which bestows the antioxidant properties to OLE (Benavente-Garcia et al., 2000). Generally, mechanisms of antioxidant action of OLE may include suppressing ROS formation either by inhibition of enzymes or chelating trace elements involved in free radical production, scavenging ROS, and upregulating and protecting antioxidant defenses.

Generally, Saalu et al. (2011) reported the antioxidative properties of MO and its ability to elevate a variety of antioxidant enzymes and testicular biomarkers. Improving volume and quality of semen and sperm production may attributed to increasing testosterone concentration, revealing pronounced effect of OLE on accessory sex glands and testicular tissues (spermatocytes) within the somniferous tubules of the testis as well as on epididymal spermatozoa (Awoniyi, 2010).

\section{Total sperm output:}

Results in Table (5) showed that sperm outputs (total, motile, live, normal and functional) per ejaculate significantly $(\mathrm{P}<0.01)$ increased in G3 and G4 as compared to G2, and inG2 than in G1, being the highest in G4. Such finding was mainly attributed to significant increasing in semen volume along with sperm cell concentration, and percentages of motility, livability and normality of spermatozoa in semen of bucks in G4 and G3 as affected by OLE treatment, respectively. As affected by collection week, sperm outputs gradually increased by advancing collection week, but this increases were insignificant only for total sperm outputs. Analysis of variance revealed that the effect of interaction between treatment and collection week was not significant on all outputs of spermatozoa.

Table (5). Sperm outputs in semen of APRI rabbit bucks fed different olive leaf extract levels at collection weeks.

\begin{tabular}{|c|c|c|c|c|c|}
\hline \multirow[t]{2}{*}{ Treatment } & \multicolumn{5}{|c|}{ Sperm output $\left(\times 10^{6}\right)$ per ejaculate } \\
\hline & $\begin{array}{l}\text { Total sperm } \\
\text { (TSO) }\end{array}$ & $\begin{array}{l}\text { Motile sperm } \\
\quad(\mathrm{MSO})\end{array}$ & $\begin{array}{l}\text { Live sperm } \\
\quad \text { (LSO) }\end{array}$ & $\begin{array}{l}\text { Normal sperm } \\
\quad(\mathrm{NSO})\end{array}$ & $\begin{array}{l}\text { Functional sperm } \\
\text { (FSO) }\end{array}$ \\
\hline \multicolumn{6}{|c|}{ Effect of olive leaf extract level : } \\
\hline G1 (control) & $73.4^{c} \pm 9.94$ & $48.7^{\mathrm{c}} \pm 11.49$ & $59.3^{\mathrm{c}} \pm 8.14$ & $64.4^{\mathrm{c}} \pm 8.63$ & $34.9^{c} \pm 8.20$ \\
\hline $\mathrm{G} 2(0.5 \mathrm{ml} / \mathrm{kg} \mathrm{diet})$ & $187.4^{\mathrm{b}} \pm 22.04$ & $141.8^{\mathrm{b}} \pm 17.15$ & $156.1^{\mathrm{b}} \pm 19.03$ & $168.8^{\mathrm{b}} \pm 20.08$ & $106.6^{\mathrm{b}} \pm 13.76$ \\
\hline $\mathrm{G} 3(1.0 \mathrm{ml} / \mathrm{kg} \mathrm{diet})$ & $239.5^{\mathrm{a}} \pm 16.85$ & $193.9^{\mathrm{a}} \pm 14.35$ & $206.3^{\mathrm{a}} \pm 16.13$ & $217.6^{\mathrm{a}} \pm 15.96$ & $152.1^{\mathrm{a}} \pm 13.35$ \\
\hline G4 (1.5 ml/kg diet $)$ & $265.0^{\mathrm{a}} \pm 17.62$ & $219.8^{\mathrm{a}} \pm 16.18$ & $230.7^{\mathrm{a}} \pm 16.87$ & $242.8^{\mathrm{a}} \pm 17.14$ & $175.6^{\mathrm{a}} \pm 14.80$ \\
\hline \multicolumn{6}{|c|}{ Effect of collection week: } \\
\hline $1-3$ & $170.8 \pm 22.86$ & $122.9^{\mathrm{b}} \pm 22.15$ & $141.0^{\mathrm{b}} \pm 20.15$ & $152.2^{\mathrm{b}} \pm 20.89$ & $91.1^{\mathrm{b}} \pm 17.31$ \\
\hline 4-6 & $185.5 \pm 23.39$ & $150.2^{\mathrm{ab}} \pm 19.86$ & $155.2^{\mathrm{b}} \pm 20.11$ & $166.5^{\mathrm{ab}} \pm 21.02$ & $113.0^{\mathrm{b}} \pm 15.47$ \\
\hline $7-9$ & $217.8 \pm 30.73$ & $180.0^{\mathrm{a}} \pm 24.93$ & $193.0^{\mathrm{a}} \pm 27.68$ & $201.6^{\mathrm{a}} \pm 28.93$ & $147.8^{\mathrm{a}} \pm 21.39$ \\
\hline \multicolumn{6}{|c|}{ Interaction between olive leaf extract levels and collection week: } \\
\hline $\mathrm{P}$-value & 0.9342 & 0.8867 & 0.8556 & 0.8764 & 0.8161 \\
\hline
\end{tabular}

$a, b$ and $c$ : Means in the same column for each factor with different superscripts are significantly different $(P<0.05)$.

Sperm cytoplasm contained very low concentrations of scavenging enzymes therefore an increase in the antioxidant enzyme levels by MO treatment could favor the reproductive process (D'cruz and Mathur, 2005). The antioxidants present in the leaves of the plant, acting in concert with the antioxidant system present in the epididymis further preserved and enhanced the process of spermatogenesis (Khalifa et al., 2016). Therefore, improving sperm outputs with increasing testosterone concentration may reveal pronounced effect of OLE on testicular tissues (spermatocytes) within the somniferous tubules of the testis as well as on epididymal

The $16^{\text {th }}$ Scientific Conference for Animal Nutrition, Luxor - Aswan, $28^{\text {th }}$ Nov. $-1^{\text {th }}$ Dec., 2017 
spermatozoa (Awoniyi, 2010). It was reported that administration of aqueous extract from MO seeds (Zade et al., 2013) or MO leaves (Khalifa et al., 2016) has positive effect on spermatogenesis in rats and rabbits, respectively. This impact may be attributing to presence of flavonoids that can ameliorate oxidative stressrelated testicular impairments in animal tissues (KujoS, 2004). The presence of flavonoids in OLE had been implicated to have a role in altering androgen levels (Padashetty and Mishra, 2007). Moreover, Shukla and Khanuja (2004) reported that steroid and saponin constituents found in many plants possess fertility potentiating properties, and they are useful in the treatment of impotence. The saponins may boost the level of testosterone in the body as well as trigger libido-enhancing effect (Gauthaman and Adaikan, 2008). Finally, Zade et al. (2013) reported that the numbers of mature Leydig cells as well as number of spermatocytes and spermatids were significantly increased in MO treated testes.

\section{Seminal plasma parameters:}

Data in Table (6) revealed that bucks in G4 showed significantly $(\mathrm{P}<0.05)$ the lowest peroxidase and fructose testes in seminal plasma as compared to other groups. However, LDH activity in seminal plasma was significantly $(\mathrm{P}<0.05)$ higher in all treatment groups than in control group, being the highest in G4. Meanwhile bucks in G1 (control) showed an opposite trend.

Table (6). Peroxidase and fructose tests and LDH activity in seminal plasma of APRI rabbit bucks fed different olive leaf extract levels at the end of collection semen period and their correlation coefficients.

\begin{tabular}{|c|c|c|c|}
\hline Treatment & $\begin{array}{l}\text { Peroxidase test } \\
\quad\left(\mathrm{U} \times 10^{3}\right)\end{array}$ & $\begin{array}{l}\text { Fructose test } \\
\quad(\mathrm{mg} / \mathrm{dl})\end{array}$ & $\begin{array}{c}\text { LDH activity } \\
(\mathrm{U} / \mathrm{l})\end{array}$ \\
\hline G1 (control) & $1.133^{\mathrm{a}} \pm 0.145$ & $279.00^{\mathrm{a}} \pm 38.35$ & $41.56^{\mathrm{c}} \pm 4.85$ \\
\hline $\mathrm{G} 2(0.5 \mathrm{ml} / \mathrm{kg} \mathrm{diet})$ & $0.633^{\mathrm{b}} \pm 0.088$ & $137.33^{\mathrm{b}} \pm 6.17$ & $86.86^{\mathrm{b}} \pm 4.40$ \\
\hline $\mathrm{G} 3(1.0 \mathrm{ml} / \mathrm{kg} \mathrm{diet})$ & $0.566^{\mathrm{b}} \pm 0.088$ & $99.33^{\mathrm{b}} \pm 8.68$ & $106.92^{\mathrm{a}} \pm 6.91$ \\
\hline $\mathrm{G} 4(1.5 \mathrm{ml} / \mathrm{kg} \mathrm{diet})$ & $0.500^{\mathrm{b}} \pm 0.057$ & $89.00^{\mathrm{b}} \pm 13.07$ & $118.88^{\mathrm{a}} \pm 7.09$ \\
\hline \multicolumn{4}{|c|}{ Correlation coefficients with sperm outputs: } \\
\hline TSO & $-0.77441 * *$ & $-0.80265^{* *}$ & $0.77724 * *$ \\
\hline MSO & $-0.75036 * *$ & $-0.80606 * *$ & $0.77407 * *$ \\
\hline LSO & $-0.77258 * *$ & $-0.818 * *$ & $0.80038 * *$ \\
\hline NSO & $-0.77125 * *$ & $-0.80909 * *$ & $0.79237 * *$ \\
\hline FSO & $-0.74026 * *$ & $-0.82081 * *$ & $0.80475 * *$ \\
\hline \multicolumn{4}{|c|}{ Correlation coefficients with semen tests: } \\
\hline Seminal fructose test & $0.91725 * * *$ & - & - \\
\hline Seminal LDH activity & $-0.84008 * * *$ & $-0.89391 * * *$ & - \\
\hline HOS-test & $-0.81177 * *$ & $-0.84695 * * *$ & $0.92957 * * *$ \\
\hline
\end{tabular}

It is of interest to note that reduction in values of peroxidase and fructose testes in seminal plasma of G4 was attributed to the lowest yield of lipid peroxidation in sperm cells and the highest consumption of fructose by spermatozoa during sperm metabolism in comparing with seminal plasma of bucks in other groups. In this respect, high quality semen should contain higher glycolytic or fructolytic rates than in semen with weak immobile sperms (Mann, 1964). The recorded lowest values of fructose test in G4 were paralleled with the highest progressive motility percentage. Yousef et al. (2003) assumed that the increases in sperm motility in semen could in part be attributed to the concomitant induction in semen fructose (Yousef et al., 2003).

Results in the current study as response to OLE as a plant natural antioxidant agreed with that obtained on MO extract as natural antioxidants. In this line, Ghodaiah (2016) reported that total antioxidant activity increased in blood of rabbit bucks orally treated with $60 \mathrm{mg}(\mathrm{P}<0.05)$ of MOE for 21 days. Also, extracts of MO increased the production of antioxidants in the sperms (Abdou et al., 2012). Moreover, Luqman et al. (2012) found that MO extract remove free radicals, activate antioxidant enzymes, and inhibit oxidases.

Results of correlation coefficients (Table 6) revealed that peroxidase or fructose test in seminal plasma correlated negatively $(\mathrm{P}<0.01)$ with each of total sperm output parameters. However, seminal LDH activity 
showed significantly $(\mathrm{P}<0.01)$ positive correlation with total sperm outputs. It is worthy noting that peroxidase and fructose tests showed negatively highly significant correlations with seminal LDH activity and HOS-t. Also, there were positive correlation between LDH activity and HOS-t $(\mathrm{P}<0.001)$ as well as between peroxidase test and fructose test $(\mathrm{P}<0.001)$. Similarly, Mostakhdem et al. (2016) found that LDH activity positively $(\mathrm{P}<0.0001)$ correlated with sperm concentration and total sperm count, while negatively $(\mathrm{P}<0.01)$ with fructose concentration and true corrected fructose.

Based on the strong correlation in peroxidase and fructose tests in seminal plasma and HOS tests in semen, the present results may suggest conducting only the HOS-t as an important test in semen for evaluation of sperm integrity and hence semen quality of rabbits.

\section{Blood serum parameters:}

Data in Table (7) revealed that liver function in term of AST and ALT activity and testosterone concentration in blood serum were not affected by OLE treatment, while ALP activity significantly $(\mathrm{P}<0.05)$ increased only in G4, while LDH activity significantly $(\mathrm{P}<0.05)$ increased in both G3 and G4 as compared to other groups.

It is worthy noting that the observed insignificant effect of OLE on AST and ALT activities, and testosterone concentration in blood serum of bucks reflected insignificant and weak correlation coefficients between each of these parameters with semen quality and sperm outputs, except high and positive correlation $(\mathrm{r}=0.610, \mathrm{P}<0.01)$ between testosterone concentration and LDH activity in seminal plasma. On the other hand, ALP in blood serum had significant correlation with net semen volume $(r=0.645, P<0.05)$, sperm outputs (concentration, total and functional spermatozoa), and seminal LDH activity $(\mathrm{r}=0.774, \mathrm{P}<0.01)$. Interestingly, LDH in blood serum positively correlated with sperm outputs and seminal LDH activity, being the strongest with sperm concentration and functional sperm outputs $(\mathrm{r}=0.842$ and $0.827, \mathrm{P}<0.001)$, followed by total sperm output and seminal LDH activity $(\mathrm{r}=0.775$ and $0.774, \mathrm{P}<0.01)$, and sperm livability $(\mathrm{r}=0.625, \mathrm{P}<0.05$, Table 7).

Table (7). Enzyme activity and testosterone concentration in blood serum of APRI rabbit bucks fed different olive leaf extract levels at the end of collection semen period.

\begin{tabular}{|c|c|c|c|c|c|}
\hline Treatment & $\begin{array}{l}\text { AST } \\
(\mathrm{IU} / \mathrm{l})\end{array}$ & $\begin{array}{l}\text { ALT } \\
(\mathrm{IU} / 1)\end{array}$ & $\begin{array}{l}\text { ALP } \\
(\mathrm{IU} / 1)\end{array}$ & $\begin{array}{l}\mathrm{LDH} \\
(\mathrm{IU} / \mathrm{l})\end{array}$ & $\begin{array}{c}\text { Testosterone } \\
(\mathrm{ng} / \mathrm{ml})\end{array}$ \\
\hline \multicolumn{6}{|c|}{ Effect of olive leaf extract level: } \\
\hline G1 (control) & $56.00 \pm 3.055$ & $60.33 \pm 1.45$ & $55.33^{\mathrm{b}} \pm 2.02$ & $1007.0^{\mathrm{b}} \pm 68.7$ & $6.26 \pm 0.34$ \\
\hline $\mathrm{G} 2(0.5 \mathrm{ml} / \mathrm{kg}$ diet $)$ & $58.67 \pm 4.630$ & $59.00 \pm 3.79$ & $62.00^{\mathrm{ab}} \pm 5.5$ & $1207.3^{\mathrm{ab}} \pm 79.4$ & $6.53 \pm 0.30$ \\
\hline $\mathrm{G} 3(1.0 \mathrm{ml} / \mathrm{kg}$ diet $)$ & $57.00 \pm 8.082$ & $57.67 \pm 4.48$ & $65.33^{\mathrm{ab}} \pm 4.6$ & $1301.7^{\mathrm{a}} \pm 81.67$ & $6.82 \pm 0.24$ \\
\hline $\mathrm{G} 4(1.5 \mathrm{ml} / \mathrm{kg}$ diet $)$ & $59.50 \pm 3.90$ & $59.67 \pm 3.28$ & $72.67^{\mathrm{a}} \pm 0.66$ & $1424.0^{\mathrm{a}} \pm 72.3$ & $7.03 \pm 0.25$ \\
\hline \multicolumn{6}{|c|}{ Correlation coefficients with volume and quality of semen: } \\
\hline Net semen volume & 0.296 & -0.063 & $0.645^{*}$ & 0.566 & 0.514 \\
\hline Sperm motility & 0.058 & 0.276 & -0.508 & -0.228 & -0.518 \\
\hline Sperm livability & 0.037 & -0.522 & 0.297 & $0.625 *$ & 0.157 \\
\hline Sperm concentration & 0.292 & -0.090 & $0.686^{*}$ & $0.842 * * *$ & 0.425 \\
\hline Total sperm output & 0.374 & -0.086 & $0.706^{*}$ & $0.775 * *$ & 0.506 \\
\hline $\begin{array}{l}\text { Functional sperm } \\
\text { output }\end{array}$ & 0.36665 & -0.13497 & $0.681 *$ & $0.827 * * *$ & 0.448 \\
\hline Seminal LDH activity & -0.025 & -0.1489 & $0.774 * *$ & $0.774 * *$ & $0.610 * *$ \\
\hline
\end{tabular}

$a, b$ and $c$ : Means in the same column with different superscripts are significantly different $(P<0.05)$.

* Significant at $P<0.05$. ** Significant at $P<0.01$. *** Significant at $P<0.001$.

Asprtate amino transaminase (AST) is a plentifully found in heart and liver muscles and plays an essential part in amino acid metabolism and pathological changes in these organs raise the activity of AST in the blood. The AST impacts the development of glutamate and oxaloacetate attributable to the transfer of the amino group from aspartate to ketoglutaric corrosive (Abdelhamid et al., 2012). The role of AST activity during the different physiological stages depends on age, breed, sex, pregnancy, natal, breast feeding, feeding systems (Milinković et al., 2005). Therefore, supplementation of the diet with natural antioxidants as OLE may affect 
feeding status. Alanine amino transaminase (ALT) is an enzyme found in the highest amount in liver and commonly used to identify injury of liver or muscle (Pratt et al., 2010). It has an effect on glutamate and pyruvate due to the transfer of the amine group from alanine to ketoglutaric acid. Increased activity of the ALT leads to the occurrence of viral hepatitis or liver damage or metabolic disorders. While, diminished ALT activity is reduced due to malnutrition or even starvation (Bagnicka et al., 2014). In agreement with the present results of OLE as a plant natural antioxidant, activity of AST and ALT exhibited non-significant changes in bucks treated with MO leaf extract (Khalifa et al., 2016), leaf and flower of MO (Luqmanet al., 2012) or green tea (GT) leaves and their extracts at different levels in serum of APRI rabbits (Morsy et al., 2013). Also, Abdo et al. (2010) found that GT supplementation had no adverse effect on liver and kidney functions for laying hens. The present results of OLE and previous data on MO and GT indicated the save usage of OLE as a natural antioxidant on normal liver function in rabbits.

The obtained results may indicate the vital role of blood ALP and LDH activities in body energy production, in particular, energy required for spermatogensis within the testes of rabbit bucks as affected by OLE treatment. The LDH is an enzyme that plays an important role in the conversion of lactate to pyruvate, which is one of the important steps in the production of energy in the cell (Perez et al., 2003). Increased blood LDH activity may be important in determining tissue damage and disease within the living body. It converts hydrogen between molecules (Goddard et al., 1997) and stimulates the last step of the glycolic path, which is the conversion from pyruvate to lactate and repetition (Bagnicka et al., 2014). In agreement with the present results, Mostakhdem et al. (2016) found that LDH activity had significant $(\mathrm{P}<0.0001)$ positive correlation with sperm concentration as well as between total sperm count and LDH activity. Also, Isitua and Ibeh (2013) showed an enhancement in the activities of ALT, AST and ALP in blood as affected by treatment of rabbits with MO leaf extract.

Testosterone is the major secretary hormone of the mature testis and spermatogenesis is controlled directly by testosterone concentration in rabbit bucks (Abdel-Khalek et al., 2005). The present concentration of testosterone in blood serum of APRI bucks in this study is higher than that reported in NZW bucks by some authors (Abd El Elmoty, 1991; Abdel-Khalek et al., 2005). Testosterone supplementation has previously been shown to improve sexual function and libido (Watchoet al., 2005; Monera et al., 2008). Plant extracts might have a role in testosterone secretion allowing better availability of hormone to gonads (Amini and Kamkar, 2005). According to the present results, OLE had beneficial effect on testosterone secretion as the role of MO in enhancing male fertility by inhibiting $6 \beta$-hydroxylation of testosterone and increasing the testosterone level (Khalifa et al., 2016), increasing blood flow to the male reproductive organs and stimulating the nervous system to enhance sexual desires (Monera et al., 2008).

Generally, improving semen quantitatively and qualitatively was associated with tendency of higher testosterone concentration in G4 than in other groups, which may reveal pronounced effect of OLE on testicular tissues (spermatocytogenesis) within the somniferous tubules of the testis as well as on epididymal spermatozoa (Awoniyi, 2010).

\section{Fertility rate:}

Results in Table (8) showed that kindling rate and reproductive index significantly $(\mathrm{P}<0.05)$ improved in G3 and G4 as compared to G2 and G1, being the highest in G4. This was associated with increasing number of total borns/group and insignificant increase of litter size/doe. These results indicated that doe rabbits mated with bucks receiving high levels of OLE ( 1.0 and $1.5 \mathrm{ml} / \mathrm{kg}$ diet $)$ recorded higher reproductive performance than in those mated with bucks fed low OLE level or control bucks, reflecting high fertility of semen produced by bucks in $\mathrm{G} 3$ and $\mathrm{G} 3$.

Motility is critical in enabling the sperm to ascend the female reproductive tract to the site of fertilization which is necessary if fertilization is to be achieved (Aitken, 1990). Free radical-induced oxidative damage to spermatozoa is a condition that has gained favorable attention for its role in inducing poor sperm function and infertility (Russo et al., 2006). Therefore, it is possible that the consumption of OLE may have a reducing or lowering capacity on ROS thereby improving fertility (Roth et al., 2002). Generally, high quality semen should contain a high percentage of vigorous and active sperms (Mann, 1964). It is of interest to observe that improving fertility of semen in bucks treated with OLE, particularly at level of $1.5 \mathrm{ml} / \mathrm{kg}$ diet was attributed to exhibiting these bucks the highest percentages of progressive sperm motility and sperm livability, and the lowest sperm abnormality percentage. In this respect, OLE as antioxidant may offer protection against the damaging effect of leukocyte-derived ROS on sperm movement (Baker et al., 1996). It is conceivable that the 
Younan et al.

increase in sperm concentration might lead to higher fertility, which supported by the findings of Oyeyemi $e t$ al. (2008).

Table (8). Reproductive performance of rabbit does mated by bucks treated with olive leaf extract at different levels.

\begin{tabular}{|c|c|c|c|c|c|c|}
\hline OLE ( $\mathrm{ml} / \mathrm{kg}$ diet) & $\mathrm{N}$ & $\begin{array}{c}\text { Number of } \\
\text { does } \\
\text { at kindling }\end{array}$ & $\begin{array}{l}\text { Kindling } \\
\text { rate }(\%)\end{array}$ & $\begin{array}{l}\text { Total } \\
\text { borns }\end{array}$ & $\begin{array}{l}\text { Litter } \\
\text { size/ doe }\end{array}$ & $\begin{array}{l}\text { Reproductive } \\
\text { index }\end{array}$ \\
\hline G1 (control) & 60 & 40 & $66.67^{c} \pm 2.108$ & 279 & $6.90 \pm 0.258$ & $4.65^{\mathrm{c}} \pm 0.232$ \\
\hline $\mathrm{G} 2(0.5 \mathrm{ml} / \mathrm{kg}$ diet $)$ & 60 & 44 & $73.33^{\mathrm{bc}} \pm 2.108$ & 316 & $7.18 \pm 0.307$ & $5.27^{\mathrm{bc}} \pm 0.116$ \\
\hline $\mathrm{G} 3(1.0 \mathrm{ml} / \mathrm{kg}$ diet $)$ & 60 & 47 & $78.33^{\mathrm{ab}} \pm 3.073$ & 349 & $7.43 \pm 0.428$ & $5.82^{\mathrm{b}} \pm 0.421$ \\
\hline G4 $(1.5 \mathrm{ml} / \mathrm{kg}$ diet $)$ & 60 & 49 & $81.67^{\mathrm{a}} \pm 3.073$ & 390 & $7.96 \pm 0.365$ & $6.50^{\mathrm{a}} \pm 0.303$ \\
\hline
\end{tabular}

\section{CONCLUSION}

Based on the foregoing results, in briefly, enhancing semen volume, sperm characteristics, seminal plasma tests, serum enzymes, and fertility trails of rabbit does, the current study can conclude that supplementation of the diet with olive leaf extract, in particular at a level of $1.5 \mathrm{ml} / \mathrm{kg}$, as a plant antioxidant source, is essential for improving reproductive performance and consequently semen quality and fertility of breeding rabbit bucks (natural or artificial mating). Further studies are needed in future to detect the effect OLE on histogenesis and histometry of both testes (spermatogenesis) and epididymis (sperm storage ability) of rabbit bucks to indicate impact of OLE on semen quality. Also, freezability of spermatozoa of bucks treated with various levels of OLE should be studied.

\section{REFERENCES}

Abaza, L.; N.B. Youssef; H. Manai; F.M. Haddada; K. Methenni and M. Zarrouk (2011). Chétoui olive leaf extracts: influence of the solvent type on phenolics and antioxidant activities. grasas y aceites, 62 (1), enero-marzo, 96-104.

Abd El Elmoty, A.K.I. (1991). Effect of reducing eating time on growth performance, reproductive performance and some blood constituents of rabbits. Egyptian J. Rabbit Sci., 1(1): 87.

Abd El Hamid, A.M.; A.E. Abdel-Khalek; T.A.M. Ashmawy; F.F.A. Ammou and H.A. El-Sanafawy (2012). Effect of dietary inclusion of whole sunflower seed on feeding lacttaiongZaraibi goats: III. On their blood profile. Animal Feed. Engormix. http://en.engormix.com.MA-feed-machinery.

Abdel-Khalek, E.A.; M.A. Abu El-Hamd and M.E. Omara (2005). Reproductive performance of New Zealand whit bucks fed diets containing different types of silage. J. Agric. Sci. Mansoura Univ., 30 (4): 1979-1991.

Abdo, Zeinab M. A.; R. A. Hassan; Abd El-Salam, Amal and Helmy, Shahinaz A. (2010). Effect of adding green tea and its aqueous extract as natural antioxidants to laying hen diet on productive, reproductive performance and egg quality during storage and its content of cholesterol. Egypt. Poult. Sci. 30 (IV): 1121-1149.

Abdou, H. S.; S. H. Salah; H. F. Booles and E. A. Abdel Rahim (2012). Effect of pomegranate pretreatment on genotoxicity and hepatotoxicity induced by carbon tetrachloride (CCl4) in male rats. Journal of Medicinal Plants Research, 6(17): 3370-3380. 
Abu, A.H.; T. Ahemen and P. Ikpechukwu (2013). The testicular morphometry and sperm quality of rabbit bucks fed graded levels of moringa oleifera leaf meal (molm). Agrosearch,; 13 (1): 49 - 56.

Aitken, R.J. (1990). Development of in vitro tests of human sperm function: a diagnostic tool and model system for toxicological analyses. Toxicol. In Vitro 4: 560-569.

Aitken, R.J.; J.S. Clarkson and S. Fishel (1989). Generation of reactive oxygen species. Lipid peroxidation and human sperm function. Biology of Reproduction. 41 :183-7.

Aliabadi, M. A.; R. K. Darsanaki; M. L. Rokhi; M. Nourbakhsh and G. Raeisi (2012). Antimicrobial activity of olive leaf aqueous extract. Annals of Biological Research, 3 (8):4189-4191.

Amini, A. and F. Kamkar (2005). The effects of gossypol on spermatogenesis in NMRI mice. Iranian J Sci Technol Trans. 29: 123-133.

Amman, R.P. and R.H. Hammerstedt (1980). Validation of a system for computerized measurements of spermatozoa velocity and percentage of motile sperm. Biol. Reprod., 23: 647-656.

Awoniyi, D.O. (2010). The role of rooibos (aspalathus linearis), green tea (camellia sinensis) and commercially available rooibos and green tea antioxidant supplements on rat testicular and epididymal function. M. Sc. Faculty of health and wellness Sci., Cape Peninsula Univ. of Technology.

Bagnicka, E.; J. Jarczak; E. Kościuczuk; J. Kaba; A. Jóźwik; M. Czopowicz; N. Strzałkowska and J. Krzyżewski (2014). Active Dry Yeast Culture Supplementation Effect on the Blood Biochemical Indicators of Dairy Goats. J Adv Dairy Res, 2:2.

Baker, H.W.; J. Brindle; D.S. Irvine and R.J. Aitken (1996). Protective effect of antioxidants on the impairment of sperm motility by activated polymorphonuclear leukocytes. Fertil. Steril. 65: 411-419.

Belfield, A. and D.M. Goldberg (1971). Revised assay for serum phenyl phosphatase activity using 4-aminoantipyrine. Enzyme. 1971;12(5):561-73.

Benavente-Garcia, O.; J. Castillo; J. Lorente; A. Ortuno and J.A. Del Rio(2000). Antioxidant Activity of Phenolics Extracted from Olea europaea L. Leaves. Food Chem. 68: 457-462.

Blom, E. (1983). Sperm Morphology with reference to bull infertility. Ludhiana, First All-India symposium on Animal Reproduction, pp.61-81.

Boiti, C.; G. Guelfi; G. Brecchia; C. Dall'Aglio; P. Ceccarelli; M. Maranesi; C. Mariottini; D. Zampini; A. Gobbetti and M. Zerani (2005). Role of endothelin-1 system in the luteolytic process of pseudopregnant rabbits. Endocrinology 146: 1293-1300.

Brun, J.M.; M. Theau-Clément and G. Bolet (2002). Evidence for heterosis and maternal effects on rabbit semen characteristics. Anim. Res., 51: 433- 442.

Cayan, H. and G. Erener (2015). Effect of olive leaf (Olea europaea) powder on laying hens performance, egg quality and egg yolk cholesterol levels. Asian Australas. J. Anim. Sci., 28(4): 538-543.

D'cruz, S. C. and P. P. Mathur (2005). Effect of piperine on the epididymis of adult male rats Asian J Androl,; 7(4): 363-368.

Dacheux, J. L.; J. L. Gatti and F. Dacheux (2003). Contribution of epididymal secretory proteins for spermatozoa maturation. Microscopy Research and Technique, 61: 7-17.

Dub, A. M. and A. M. Dugani (2013). Antithrombotic effect of repeated doses of the ethanolic extract of local olive (Olea europaea L.) leaves in rabbits. Libyan J. Med., 8: 1-6.

Duncan, D.B. (1955). Multiple range and multiple F-test. Biometrics, 11:1-42.

Eid, Y.; T. Ebeid and H. Younis (2006). Vitamin E supplementation reduces dexamethasone-induced oxidative stress in chicken semen. Br. Poult. Sci. 47: 350-356.

Feldman, H.A.; C.B. Johannes; C.A. Derby; K.P. Kleinman; B.A. Mohr; A.B. Araujo and J.B. McKinlay (2000). Erectile dysfunction and coronary risk factors: prospective results from the Massachusetts male aging study. Preventive Medicine, 30: 328-338. 
Foreman, D.; L. Gaylor; E. Evans and C. Trella (1973). A modification of the Roe procedure for determination of fructose in tissues with increased specificity. Analytical Biochemistry. 56(2):584-590.

Gauthaman, K. and P.G. Adaikan (2008). The hormonal effects of Tribulusterrestris and its role in the management of male erectile dysfunction--an evaluation using primates, rabbit and rat.Phytomedicine, 15 (1): 44- 54 .

Ghodaiah, A.E.B. (2016). Studies on semen quality and preservation of rabbit bucks fed moringa oleifera extracts. PH. D. Thesis, Mansoura University.

Goddard, P.J.; G. Keay and P.N. Grigor (1997). Lactate dehydrogenase quantification and isoenzyme distribution in physiological response to stress in red deer (Cervuselaphus). Res Vet Sci 63: 119-122.

Hackett, A.J. and W. Macpherson (1965). A method for differential staining of bovine spermatozoa after extension in sterile milk. Can Vet. J. 6(5): 117-118, 119-120.

Hassan, M.A. (2015). Some morphological, ltrastructural and biochemical changes during different freezing bulls semen processes using electron microscope. M.Sc. Thesis, Mansoura University.

Huang, S.L.; L. Zhang; P.L. Huang; Y.T. Chang and P.L. Huang (2003). Anti-HIV activity of olive leaf extract (OLE) and modulation of host cell gene expression by HIV-1 infection and OLE treatment. Biochemical and Biophysical Research Communications, 307 (4): 1029-1037.

Isitua, C.C. and I.N. Ibeh (2013). Toxicological Assessment of Aqueous Extractof Moringa Oleiferaand Caulis BambusaeLeaves in RabbitsJ Clinic Toxicol, 12:2-4.

Juven, B.; Y. Henis and B. Jacoby (1972). Studies on the Mechanism of the Antimicrobial Action of Oleuropein. Journal of Applied Bacteriology, 35 (4): 559-567

Khalifa, Walaa H.; F.M. Ibrahim, Aida I. El Makawy; Hafiza A. Sharaf; W.B. Khalil and Nagwa A. Maghraby (2016). Safety and fertility enhancing role of moringa oleifera leaves aqueous extract in New Zealand Rabbit bucks. Int j pharm; 6(1): 156-168.

KujoS (2004). Vitamin C: basic metabolism and its function as an index of oxidative stress. Curr Med Chem, 11: 1041-1064.

Luqman, S.; S. Srivastava; R. Kumar; A.K. Maurya and D. Chanda (2012). Experimental assessment of Moringa oleifera leaf and fruit for its antistress, antioxidant, and scavenging potential using in vitro and in vivo assays. Evidence-Based Complementary and Alternative Medicine, 1-12.

Mangiagalli, M.G., V. Cesari; S. Cerolini; F. Luzi and I. Toschi (2012). Effect of lycopene supplementation on semen quality and reproductive performance in rabbit. World rabbit sci., 20: 141-148.

Mann, T. (1964). Metabolism of semen: fructolysis, respiration, and sperm energetics. In: The Biochemistry of Semen and the Male Reproductive Tract. Wiley, New York, USA, pp. 265-307.

McCann, D.; L. Kirkish (1985). Evaluation of free testosterone in serum. J Clin Immunoassay.; 8:234-6.

Milinković-Tur, Suzana, VedranaPerić, ZvonkoStojević, Maja Zdelar-Tuk, and JasnaPiršljin (2005). Concentrations of total proteins and albumins, and AST, ALT and GGT activities in the blood plasma of mares during pregnancy and early lactation. Veterinarski Arhiv, 75 (3): 195-202.

Monera, T.G.; A.R. Wolfe; C.C. Maponga; L.Z. Benet and J. Guglielmo (2008). Moringa oleifera leaf extracts inhibit 6-hydroxylation of testosteronee by CYP3A4. J Infect Dev Ctries. 2: 379-383.

Morsy, W. A.; Ayat A. Ragab; A. I. Abd El-Lateif and M. A. M. Sheteifa (2013). Effect of adding green tea leaves in diet and its aqueous extract in water as natural antioxidants on growth performance, digestiblity coefficeints and some blood parameters of growing rabbits. Proceeding of the 4th scientific conference of Animal Production Research Institute, November 12-13th, 2013, Dokki, Giza, Egypt. Pp. 420-432.

Mostakhdem, H. M.; A. Tabandeh; T. Tajari; N. Behnampour; A. Aliarab and H. R. Joshaghani (2016). Evaluation of LDH Activity and Its Relationship with Fructose Levels in Seminal Plasma of Normospermic and Asthenospermic Males. Medical Laboratory Journal, 10 (4) : 18-23. 
Oliveira, L. Z.; V. F. Hossepian de Lima.; M. A. Levenhagen.; R. M. Santos.; T. I. Assumpcao.; J. O. Jacomini.; A. F. Andrade.; R. P. Arruda and M. E. Beletti (2011). "Transmission electron microscopy for characterization of acrosomal damage after Percoll gradient centrifugation of cryopreserved bovine spermatozoa." J. Vet. Sci., 12(3): 267-272.

Ong, C.N.; H.M. Shen, and S.E. Chia (2002). Biomarkers for male reproductive health hazards: are they available? Toxicol. Letters, 134: 17-30.

Ongun Uysal; Çiğdem Çebi; Ömer Varişli; Mehmet Borga Tirpan and Derya Dinçel (2010). In vitro evaluation of principle spermatological parameters in different rabbit breeds. Ankara Üniv., Vet. Fak. Derg, 57: 135-137.

Oyeyemi, M.O; S.G. Olukole and O. Esan (2008). Sperm morphological studies of West African Dwarf Bucks treated with pumpkin plant (Cucurbita pepo). Int J Morphol. 26:121-126.

Padashetty, S.A. and S.H. Mishra (2007). Aphrodisiac Studies of Tricholepisglaberrima. Antioxidant Enzymes Pharmaceutical Biol; 45(7): 580-586.

Perez, J.M.; F.J. Gonzalez; F.J. Granados; M.C. Perez; P. Fandos and R.C. Sorigner (2003). Haematologic and biochemical reference intervals for Spanish ibex. $J$ WildlDis ; 39: 209-215.

Periera, A. P.; I. C. Ferreira; F. Marcelino; P. Valentao; P. B. Andrade; R. Seabra; L. Estevinho; A. Bento and J. A. Pereira (2007). Phenolic compounds and antimicrobial activity of olive (Olea europaea L. Cv. Cobrancosa) leaves. Molecules, 12(5): 1153-1162.

Pratt, D.S. (2010). Liver chemistry and function test. In: Gastrointestinal and liver diseases. Feldman, M. Friedman L.S., Brandt L.J. Sleisenger and Fordran S. Philadelphia: Elseviers Publishers, p. 118-124.

Purdy, P.H.; S.A. Ericksson; R.E. Dodson; K.L. Sternes and D.L. Garner (2004). Effects of flavonoids, silibinin and catechin on the motility of extended cooled caprine sperm. Small Ruminant Research, 55: 239-243.

Roth, E.; O. Rudolf; N. Manhart; R. Exner; B. Wessner; E. Strasser and A. Spittler (2002). Regulative potential of glutamine-regulation to glutathione metabolism. Nutr., 18: 217-221.

Russo, A.; N. Troncoso; F. Sanche; J.A. Garbarino and A. Vanella (2006). Propolis protects human spermatozoa from DNA damage caused by benzo [a] pyrene and exogenous reactive oxygen species. Life Sci., 78: 1401-1406.

Saalu, L.C; A.A. Osinubi; A.A. Akinbami; O.E. Yama; A.O. Oyewopo and B.U. Enaibe (2011). Moringa oleifera Lamarck (drumstick) leaf extract modulates the evidences of hydroxyurea-induced testicular derangement. International Journal of Applied Research in Natural Products.; 4(2):32-45.

SAS (2004). SAS/STAT User's Guide. Version 8, Statistical Analysis Systems Institute, Inc., Cary, NC., USA.

Shafey, T. M.; S. I. Almufarij and H. A. Albatshan (2013). Effect of feeding olive leaves on the performance, intestinal and carcass characteristics of broiler chickens. Int. J. Agric. Biol., 15: $585 \square 589$.

Sharma R.K. and A. Agarwal (1996). Role of reactive oxygen species in male infertility. Urology., 48: 835850.

Sherwin J.E. (1984). Liver Function. In: Clinical chemistry, theory, analysis, and correlation. Kaplan L.A., Pesce A.J., eds. St. Louis: Mosby:420-438.

Sheteifa, M.A.M and W.A. Morsy (2014). Effect of green tea (camellia sinensis) as dietary supplements on semen quality and testosterone profile in rabbits. J.Animal and Poultry Prod., Mansoura Univ., Vol.5 (1): $1-13$.

Shukla, V.N. and S.P.S. Khanuja (2004). Chemical, pharmacological and botanical studies on Pedalium murex. J. Med. Aromatic Plant Sci. 26: 64-69.

Sikka, S.C. (2001). Relative impact of oxidative stress on male reproductive function. Current Medi. Chem., 8: $851-862$. 
Sudjana, A. N.; C. D'Orazio; V. Ryan; N. Rasool; J. Ng; N. Islam; T. V. Riley and K. A. Hammer (2009). Antimicrobial activity of commercial Olea europaea (olive) leaf extract. Int. J. Antimicrob. Agents, 33: 461-463.

Suresh, S.; E. Prithiviraj and S. Prakash (2009). Effect of Mucuna pruriens on oxidative stress mediated damage in aged rat sperm. International J. Andrology, 33: 22-32.

Watcho, P.; M.M. Donfack; F. Zelefack; T.B. Nguelefack; S.L. Wansi; F. Ngoula; P. Kamtchouing; E. Tsamo and A. Kamanyi (2005). Effects of the hexane extract of Mondiawhitei on the reproductive organs of male rat. Afr J Trad CAM. 2:302-311.

Young, DS. (1990). Effects of drugs on clinical laboratory tests. Third edition. 1990 :3:6-12.

Yousef, M.I.; G.A. Abdallah and K.I. Kamel (2003). Effect of ascorbic acid and Vitamin E supplementation on semen quality and biochemical parameters of male rabbits. Anim. Reprod. Sci. 76: 99-111.

Zade, S.V.; K.D. Dabhadkar; G.V. Thakare and R.S. Pare (2013). Effect of aqueous extract of moringa oleifera seed on sexual activity of male albino rats. Biological Forum - An International J. 5(1): 129-140. 


\title{
جودة السائل المنوي ومستوي هرمون التيستوستيرون وبعض الأنشطة الإنزيمية والخصوية في ذكور الأرانب الأبرى المعاملة بمستويات مختلفة من مستخلص هرئل أوراق الزيتون
}

\author{
جورج عزت يونان وهدي السيد الجابري و وائل عوض محمود مرسى \\ معهل بحوث الإنتاج الحيوانسي- مركز البحوث الزراعيةـ اللقيـ- مصر.
}

تلهدف الدراسة الحالية الي تقييم اضافة مستويات مختلفة من المستخلص الكحولى لأوراق الزيتون (ايثانول) فى العليقه، كمصدر لمضادادات

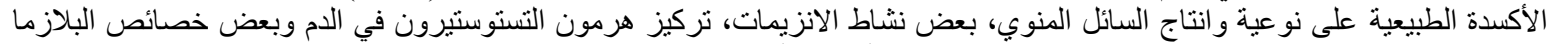

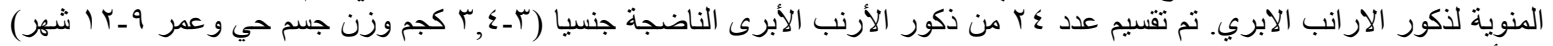

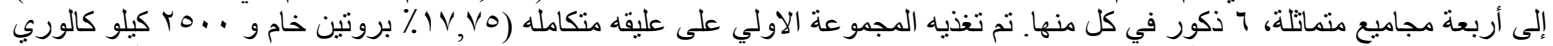

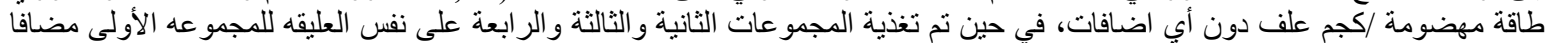

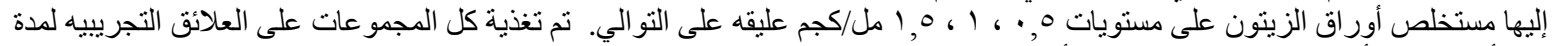

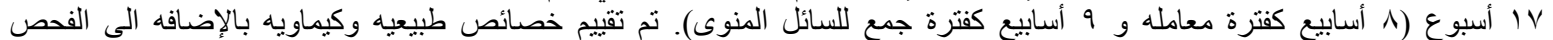
بالميكروسكوب الألكترونى للسائل المنوى لجميع المجمو عات. أظهرت الدراسه النتائج الأتيه:

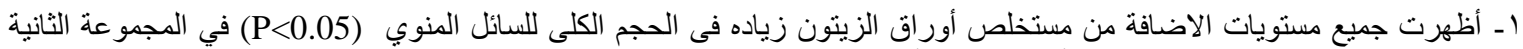

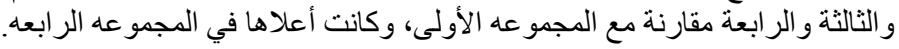

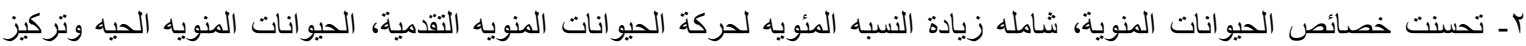

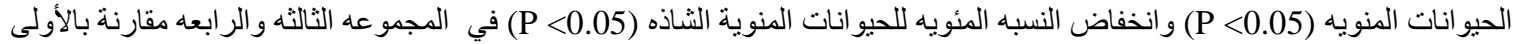
و الثانيه.

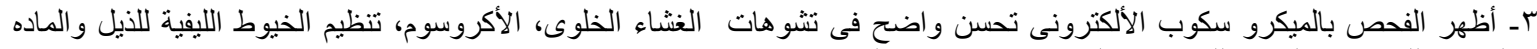

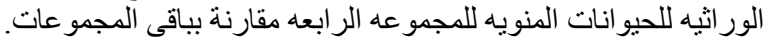

عـ أظهرت المجموعه الرابعه أدنى مستوى (P > P) لأختبارى البيروكسيديز والفركتوز في البلازما المنوية مقارنة مع المجموعات الأخرى.

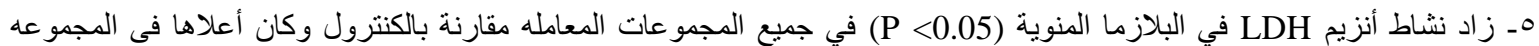
الر ابعها و أقلها في المجمو عهد الأولى.

T- لم تؤثر المعاملات فى نشاط كل من AST \& ALT وتركيز التستوستيرون في مصل الدام.

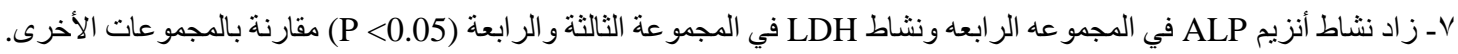

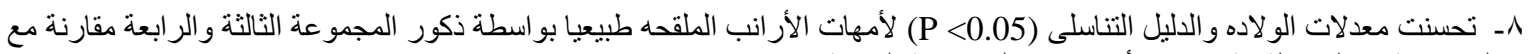

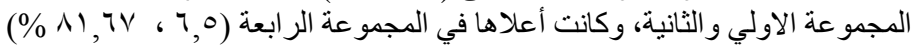

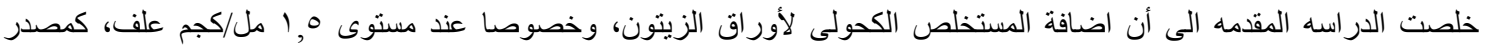

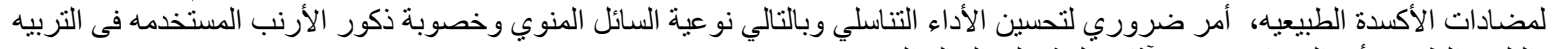
(التلقيح الطبيعي أو الصناعي) دون آثار سلبية على الحاله الصحيه. 